\title{
LEGO MINDSTORMS IN THE TEACHING OF JAVA PROGRAMMING
}

\author{
Ingrid NAGYOVÁ
}

\begin{abstract}
When teaching programming, various methods and procedures are used, think of the method of successive steps, methods of sample examples or design patterns. Whether we apply any of these methods in teaching, the introduction of basic programming structures will be an essential part of the course. The same is the case with teaching programming language Java. Even though it is an objectoriented programming language, the data manipulation and the basic programming structures (initialization of variables, looping and program branching, etc.) can't get around in the teaching.

The aim of this paper is to introduce the possibility of the teaching of algorithms and basic programming structures in Java language using Lego Mindstorms. Java development environment enhanced with the ability of Lego Mindstorms ot control allows virtually solve real-world tasks for branching (for example, "if it is red, stop" or "if the obstacle is in front of you, go around it") and looping (e.g. as "always go round"). The paper presents a procedure of teaching, how it can implemented in teaching of the basics of Java programming using Lego Mindstorms, using their servomotors and sensors.
\end{abstract}

Key words: algorithm development, programming, education, e-learning, Java, Lego Mindstorms.

\section{LEGO MINDSTORMS VE VÝUCE PROGRAMOVÁNÍ V JAZYCE JAVA}

Resumé: Při výuce programování se využívají různé metody a postupy, vzpomeňme např́klad metodu postupných kroků, metodu vzorových př́kladů nebo návrhových vzorů. At' ve výuce uplatníme kteroukoliv z těchto metod, seznámení se základními programovacími strukturami bude nezbytnou součástí výuky. Nejinak je tomu i u výuky programovacího jazyka Java. I přesto, že se jedná o objektově orientovaný programovací jazyk, práci $\mathrm{s}$ daty a základní programovací struktury (inicializace proměnných, opakování a větvení programu apod.) nelze ve výuce obejít.

Smyslem př́spěvku je představit možnost výuky algoritmizace a základních programovacích struktur v jazyce Java pomocí stavebnice Lego Mindstorms. Vývojové prostředí jazyka Java rozšířené o možnosti ovládání Lego Mindstorms umožní prakticky řešit úlohy reálného světa pro větvení (např́klad „pokud je červená, zastav“ nebo „pokud je před tebou překážka, obejdi ji“) a opakování (např́klad „pořád jdi dokola“). Př́ispěvek představuje postup výuky, jak ji lze realizovat ve výuce základů programování v jazyce Java pomocí robotů Lego Mindstorms, s využitím jejich servomotorů a senzorů.

Klíčová slova: algoritmizace, programování, výuka, e-learning, Java, stavebnice Lego Mindstorms.

\section{1 Úvod}

Výuka algoritmizace a programování, rozvoj algoritmického myšleni a algoritmického př́stupu $\mathrm{k}$ řešení problémů patří $\mathrm{k}$ nejobtížnějším oblastem informatického vzdělávání na všech stupních škol a ve všech studijních oborech [3]. Algoritmizace a programování jsou oblasti informatiky obtížné vysokou mírou abstrakce a představivosti, nutností exaktního př́stupu, jasností a srozumitelností vyjadřování. Při návrhu algoritmů je nutný nadhled na proces řešení problémů - od pamatování si toho, jak řešení od začátku probíhalo až $\mathrm{k}$ jisté předvídavosti a představě o dalším postupu řešení. Výuka algoritmizace a práce na vývoji softwaru tak vyžadují nejenom teoretické znalosti a zručnosti práce ve vhodném vývojovém prostředí, ale také jisté osobností předpoklady a jejich rozvoj.

Náročnost algoritmizace a programování a nutných souvisejících dovedností a schopností se následně odráží v demotivaci studentů, jejich neochotě ke spolupráci, která často přerůstá v ztrátu zájmu o studovaný obor [11]. Tyto dopady jsou ještě větší, jedná-li se o studenty oborů, v nichž není programování stěžejní oblastí, tj. v nichž studenti nejsou připravování prímo pro profesi programátorů. Taková je situace např́klad u studentů učitelských oborů se zaměřením na vzdělávání v oblasti informatiky. 
Nezájem studentů o výuku základů algoritmizace a programování nutí učitele těchto předmětů $\mathrm{k}$ hledání cest ke zvýšení atraktivnosti výuky, k vyšší motivovanosti studentů. Tato snaha učitelů o zatraktivnění informatiky a informatického př́stupu $\mathrm{k}$ řešení problémů zde byla dřive, než první osobní počítače. Vzpomeňme např́iklad práci Seymoura Paperta [12], která vedla již v roce 1967 k vývoji programovacího jazyka Logo určeného dětem jako nástroj pro rozvoj myšlení a výuku procesu řešení problémů. Od té doby bylo o výuce algoritmizace a rozvoji algoritmického myšlení napsáno mnohé, mnoho učitelů neustále hledá nové a netradiční postupy výuky, navrhuje nová výuková či dokonce vývojová prostředí na míru potřeb svých žáků a studentů.

Smyslem tohoto př́spěvku je poukázat na možnosti zatraktivnění výuky programování $\mathrm{v}$ jazyce Java pomocí robotů sestavených ze stavebnic Lego Mindstorms [8]. Př́spěvek stručně seznamuje s jednotlivými částmi robotů Lego Mindstorms a přináší ucelený koncept výuky základních programových struktur s využitím senzorů Lego Mindstorms a jejich vlastností.

Výsledky a závěry př́spěvku jsou obecně uplatnitelné ve výuce algoritmizace a základů programování. Cílovou skupinou, pro kterou je výuka připravována, jsou studenti oboru Informační technologie ve vzdělávání, který je vyučován na Pedagogické fakultě Ostravské univerzity. Tito studenti jsou připravováni na pozice koordinátorů a dalších IT specialistů pro různé typy škol, od základních a středních škol až k podnikovému vzdělávání a dalším formám celoživotního učení se. Jedná se tudíž o studenty, pro které programování není cílovou kompetencí. Naopak - programování je pro tyto studenty náročnou oblastí, jehož význam pro svou budoucí profesi chápou jen velice obtížně. Hledání vhodných motivačních prvků, pestrost a nápaditost výuky, její smysl a logická výstavba jsou zde požadovány a odůvodněny více než $\mathrm{v}$ jiných informaticky zaměřených oborech.

Předmět zaměřený na objektově orientované programování $\mathrm{v}$ jazyce Java je zařazen do studijního plánu navazující magisterského studia. Pro většinu studentů představuje předmět první setkání s jazykem Java. V předchozím bakalářském studiu studenti absolvují předměty zaměřené na algoritmizaci a základy programování. Programovacími jazyky jsou Object Pascal a různé implementace jazyka Logo
(Imagine, Scrach apod.), které studenti mohou dále uplatnit při práci $\mathrm{s}$ dětmi ve školním prostředí nebo zájmových koužcích.

\section{Lego Mindstorms}

Lego Mindstorms jsou robotické stavebnice firmy Lego, které obsahují tzv. programovatelnou kostku [9]. Roboti a další stavby seskládané $\mathrm{z}$ těchto stavebnic jsou ovladatelné pomocí prríkazů zadávaných přímo prostřednictvím kostky nebo pomocí programů vytvářených ve speciálním programovém prostředí NXT-G dodávaným společně se stavebnicí. Programové ovládání robotů je jednoduché. V programovém prostředí NXT-G se využívá programovací jazyk sestávající z ikon (bloků), které se skládají za sebe. Ikony mají volitelné parametry a ovlivňují tak chování a vnímání robota.

Jak bylo naznačeno, centrální jednotkou robota je programovatelná kostka. Pro pohyb robota slouží motorky (tzv. servomotory), jež se mohou zadanou rychlostí otáčet o určitý počet stupňů vpřed nebo vzad a slouží obvykle jako hnací síla robota pro pohon kol.

Pro vnímání vnějšího prostředí (překážek, hluku, barvy apod.) může robot využít senzory, které jsou jakýmisi smyslovými orgány robota. Ultrazvukový senzor zjištuje vzdálenost robota od určité překážky. Indikace překážky před robotem se provádí pomocí tlakového senzoru reagujícího na zmáčknutí nebo tlak. Světelný senzor indikuje barevnost aktuálně osvětlené plochy. Zvukový senzor reaguje na výrazný zvukový signál ve formě tlesknutí nebo hlasité mluvy. Lze využít i další senzory podle zájmu a úkolu, který chceme řešit.

Robotické stavebnice jsou velice oblíbené zejména u žáků druhého stupně základní školy. Svoji motivační úlohu neztrácí ani v pozdějším věku a ukazuje se, že mohou být vhodným prostředkem výuky i pro studenty vysokých škol. To samozřejmě předpokládá zvýšení požadavků na znalosti a dovednosti $\mathrm{v}$ práci s robotem a na jeho ovládání. Starší žáci a studenti vítají řešení složitějších úloh. K ovládání robotů sestavených ze stavebnic Lego Mindstorms lze využít také programovací jazyk Java ve vývojovém prostředí Eclipse. K tomu je potřeba stáhnout a nainstalovat LeJOS NXT software, který kromě potřebného firmwaru pro robotickou kostku obsahuje také potřené nástroje a knihovny pro programování robota $\mathrm{v}$ jazyce Java ve vývojovém prostředí NetBeans nebo Eclipse. Použití klasického programovacího jazyka Java je 
nejpokročilejší metodou programování stavebnic Lego Mindstorms a umožňuje využití robotických stavebnic ve výuce algoritmizace a programování i na vysokých školách [13].

O programovatelných robotech Lego Mindstroms bylo mnoho napsáno, existuje mnoho materiálů pro podporu výuky práce $\mathrm{s}$ robotem a jeho programování. Za všechny vzpomeňme projekt Robotické vzdělávání [6], který podrobně mapuje práci s robotem v prostředí NXT-G a RobotC. Každoročně se pořádají soutěže $\mathrm{v}$ ovládání a programování robotů [5] nebo lze najít př́klady a náměty na stavbu nejrůznějších konstrukcí a na jejich programové rrízení. Dostupné informace a portály jsou však obvykle zaměřeny na jiná programová prostředí než jazyk Java nebo jsou pro úvodní seznámení se $\mathrm{s}$ programováním $\mathrm{v}$ tomto prostředí poměrně složitá.

Přesto se jazyk Java pro programování robotů Lego Mindstorms využívá, a to zejména na technicky zaměřených vysokých školách. V České republice se s touto variantou výuky můžeme setkat např́klad na Českém vysokém učení technickém v Praze [5]. Robotické stavebnice Lego Mindstorms jsou ve spojení s jazykem Java využívány ve výuce i v zahraničí, vzpomeňme např́íklad Bernskou univerzitu ve Švýcarsku [1] nebo univerzity ve Velké Británii [2] [4].

\section{Výuka programování $v$ jazyce Java pomocí Lego Mindstorms}

Java je objektově orientovaný jazyk. Patři k nejpopulárnějším a nejpouživanějším jazykům na světě. Jeho největší výhodou je snadná přenositelnost a jednoduchost. Jeho výhodou pro využití ve výuce je snadná dostupnost a dodržování zásad a pravidel tzv. „slušného“ programování, jako jsou typová kontrola, členění programu do podprogramů (metod), deklarace proměnných apod.

Pro správnou tvorbu programů v jazyce Java je nutné znát základní pravidla objektově orientovaného programování. Když ovšem pomineme objektovou strukturu vytvářených programů, lze jazyk Java využít i k výuce algoritmizace a základních programových struktur, jako jsou opakování a větvení programů apod. Pro zvýšení motivace $\mathrm{k}$ náročné výuce základů programování a zlepšení provázaností mezi znalostmi algoritmizace a programováním lze vhodně využít právě robotů sestavených ze stavebnic Lego Mindstorms. Orientace výuky se tak přesouvá z pouhého předávání vědomostí a z abstraktního uvažování na jednání a řešení reálných problémů, kdy si studenti osvojují znalosti a dovednosti aktivní tvorbou jako jednotlivci nebo ve skupině [15].

Programovací jazyk Java nebyl navržen př́mo pro vzdělávání a jeho výuka není, již z důvodů využívání objektů, jednoduchá [14]. Jeho velkou výhodou proti klasickým jazykům používaným pro výuku je motivace studentů a jejich počáteční nadšení pro tento jazyk, které jednoznačně vychází zobecné oblíbenosti Javy, její nezávislosti na platformě a požadavků pracovního trhu na informatické profese. Jazyk Java je proto pro výuku i přes mnohá úskalí využívaný a poměrně oblíbený.

Dále uvedeme postup výuky základů programování v jazyce Java s využitím Lego Mindstorms. Nejprve rozebereme základní algoritmické struktury (opakování a větvení) a možné úkoly pro řešení ve vztahu k jednotlivým prvkům robota Lego Mindstorms (kostka, servomotory, senzory). Následně navrhneme a popíšeme postup výuky.

\section{1 Úkoly pro Lego Mindstorms}

Základní činnosti, které může robot Lego Mindstorms vykonat, jsou ujet dopředu danou vzdálenost a otočit se o určitý počet stupňů vlevo nebo vpravo. Robot tak může napríklad jezdit tam a zpět tak, že pojede dopředu a pak se otočí do protisměru a tyto dvě činnosti bude několikrát opakovat. Opakování činnosti pohybu dopředu a točení o určitý úhel umožňuje robotovi projet libovolný n-úhelník, napríklad čtverec, trojúhelník apod. Pokud je počet vrcholů n-úhelníku dostatečně velký, robot projde dráhu kruhu. Ve všech těchto př́padech robot danou činnost zopakuje několikrát, přičemž je dán pevný počet opakování.

Robot může jet dopředu nebo se otáčet také bez udání vzdálenosti nebo počtu stupňủ pro otočení. V tom př́padě jede dopředu tak dlouho, pokud například nenarazí na překážku, nezazní zvukový signál nebo se nezmění barva podložky. Pokud nastane některá z uvedených situací, robot ukončí svůj pohyb. Zde není dán pevný počet opakování činnosti robota, robot opakuje svoji činnost tak dlouho, než dojde $\mathrm{k}$ splnění, resp. nesplnění dané podmínky.

Situace, do nichž se robot dostává, lze řešit také změnou $\mathrm{v}$ chování robota. $\mathrm{V}$ takových prŕpadech robot situaci pouze vyhodnotí a rozhoduje se pro další činnost. Větvení lze 
využít např́klad, pokud se robot dostane do blízkosti nějaké překážky a musí se před ní otočit nebo pokud detekuje červenou nebo zelenou barvu a musí se podle toho rozhodnout, zda má zastavit nebo jet dále. Zajímavým príkladem může být vytvoření parkovacího asistenta, tzn. zaparkování robota na základě detekce překážky vpředu, resp. vzadu.

Větvení činnosti robota může být složitějšš (vícecestné), pokud robot reaguje na více úrovní vzdálenosti, více barev nebo různou intenzitu zvuku. Vícecestné větvení využijeme také při detekci tlačítek na kostce (šipka doleva, doprava, výběr a zrušení) a předefinování jejich funkcí. Např́iklad šipky na kostce robota mohou sloužit ke změně směru robota (jízdě dopředu nebo dozadu) nebo k mírnému natočení robota vlevo nebo vpravo.

Při snímání různých úrovní barev, zvuků, vzdáleností apod. lze využít složitější datové struktury, naprríklad pole kódů nebo názvů barev.

\subsection{Koncepce výuky základů programování}

Výuka základů algoritmizace a programování $\mathrm{v}$ jazyce Java s využitím Lego Mindstorms předpokládá následující předchozí znalosti:

- základní znalosti a dovednosti v práci v prostředí Eclipse - vytvoření projektu, orientace v prostředí, vytvoření třídy, spouštění programů apod.;

- znalost deklarace a inicializace proměnných;

- pochopení sekvenčního principu řazení a vykonávání prríkazů při programování;

- znalost základů objektově orientovaného programování, tj. deklarace tříd, vytváŕení objektů, atributy a metody tř́d, konstruktor.

Uvedené znalosti nejsou nutnou podmínkou zahájení výuky. S některými lze studenty seznamovat průběžně (práce v prostředí Eclipce, deklarace proměnných apod.), jiné lze prezentovat jako fakta, jejichž význam bude objasněn později (např́iklad deklarace a vytvoření objektu, konstruktor apod.).

Nutnou podmínkou je instalace všech potřebných programů, ovladačů a firmwaru $\mathrm{v}$ robotické kostce a propojení robota s počítačem přes USB kabel nebo pomocí Bluetooth.

Vlastní výuka je rozdělena do šesti tematicky zaměřených okruhů. Každý z nich je zaměřen na vybranou algoritmickou a programovou strukturu (opakování, větvení) a také na vhodnou část robota Lego Mindstorms (servomotor, senzor, kostku apod.). Stručný návrh výuky v části algoritmizace a programování a $\mathrm{v}$ části práce s robotem předkládá tabulka 1 . Výuka začíná programovou strukturou pro opakování - cyklem for. Je provázána se seznámením se se servomotory, které zabezpečují pohyb robota Lego Mindstorms (lekce 1). Pevný počet opakování určený cyklem for je v dalších lekcích nahrazen omezením počtu opakování pomocí podmínky (cyklus while). Omezující podmínky jsou z principu robotů Lego Mindstorms navázány na jednotlivé senzory. Opakovaný pohyb robota je omezován nejprve pomocí dotykového a zvukového senzoru (lekce 2 a 3).

Tabulka 1: Průběh výuky

\begin{tabular}{|c|c|}
\hline $\begin{array}{l}\text { Algoritmizace a } \\
\text { programování }\end{array}$ & Lego Mindstorms \\
\hline \multicolumn{2}{|c|}{ Lekce 1: Cyklus for, servomotory } \\
\hline $\begin{array}{c}\text { Opakování - pevný počet } \\
\text { opakování }\end{array}$ & $\begin{array}{c}\text { Deklarace a vytvoření } \\
\text { objektu (robota) }\end{array}$ \\
\hline \multirow[t]{2}{*}{ Cyklus for } & Servomotory - levý a pravý \\
\hline & $\begin{array}{c}\text { Jízda vpřed, vzad, otočení } \\
\text { vlevo, vpravo, jízda po } \\
\text { oblouku }\end{array}$ \\
\hline \multicolumn{2}{|c|}{ Lekce 2: Cyklus While, dotykový senzor } \\
\hline $\begin{array}{l}\text { Opakování - ukončeno } \\
\text { podmínkou na začátku }\end{array}$ & Dotykový senzor \\
\hline Cyklus While & Detekce zmáčknutí senzoru \\
\hline \multicolumn{2}{|c|}{ Lekce 3: Cyklus Do-While, zvukový senzor } \\
\hline $\begin{array}{l}\text { Opakování - ukončeno } \\
\text { podmínkou na konci }\end{array}$ & Zvukový senzor \\
\hline \multirow[t]{2}{*}{ Cyklus Do-While } & Detekce zvukového signálu \\
\hline & $\begin{array}{c}\begin{array}{c}\text { Vytvoření zvukového } \\
\text { signálu }\end{array} \\
\end{array}$ \\
\hline \multicolumn{2}{|c|}{ Lekce 4: Podmínka If, ultrazvukový senzor } \\
\hline Větvení & Ultrazvukový senzor \\
\hline \multirow[t]{2}{*}{ Podmíněný příkaz If } & Detekce vzdálenosti \\
\hline & $\begin{array}{l}\text { Reakce robota na danou } \\
\text { vzdálenost od překážky }\end{array}$ \\
\hline \multicolumn{2}{|c|}{ Lekce 5: Příkaz Switch, tlačítka na kostce } \\
\hline Vícecestné větvení & Tlačítka na robotické kostce \\
\hline Př́íkaz Switch & Detekce zmáčknutí tlačítka \\
\hline \multicolumn{2}{|c|}{ Lekce 6: Pole, světelný senzor } \\
\hline \multirow[t]{2}{*}{$\begin{array}{l}\text { Typ pole, deklarace, } \\
\text { inicializace }\end{array}$} & Světelný senzor \\
\hline & $\begin{array}{c}\text { Detekce barev } \\
\text { zaznamenaných senzorem }\end{array}$ \\
\hline
\end{tabular}

Později se zaměřujeme na rozhodovací činnosti robota a programovou strukturu větvení, která je ve výuce primárně navázána na ultrazvukový senzor (lekce 4). Praktické př́iklady umožňují procvičení struktury větvení rovněž s pomocí senzorů probíraných v předchozích etapách výuky. Pro strukturu vícecestného větvení se nabízí detekce čtyř tlačítek na robotické kostce (lekce 5).

Znalost deklarace a inicializace proměnných základních datových typů je nutným požadavkem pro výuku programování $\mathrm{v}$ Javě pomocí robotů 
Lego Mindstorms. Závěrečná lekce rozšiřuje tyto znalosti o proměnné strukturovaného datového typu pole, kterých je zde primárně využito $\mathrm{k}$ detekci barev zaznamenaných světelným senzorem (lekce 6).

\subsection{Př́klady k jednotlivým tématům}

Ve výuce programování je důležité vysvětlovat a aplikovat znalosti na reálných a smysluplných př́kladech, s nimiž se studenti nejprve pouze seznamují a zkouší je a postupně se pokouší o hledání vlastních řešení úkolů $\mathrm{s}$ různou mírou obtížnosti. Předností robotických stavebnic a jejich využití ve výuce programování je to, že řešené prríklady mohou zrcadlit reálné situace, reálné opakované činnosti nebo reálné rozhodovací procesy. Dále uvádíme prŕklady, které lze ve výuce v rámci jednotlivých lekcí řešit.

Cyklus for (lekce 1) lze procvičit na príkladech jízdy robota po pravidelných útvarech, jako jsou čtverec, trojúhelník, pentagram nebo kruh. Při řešení těchto jednoduchých úkolů nutno upozornit na nepřesnosti jízdy a otáčení robota při pohybu po různých podkladech. Nepřesnosti rostou s počtem opakování, procházka pro kruhu se proto může snadno změnit v pohyb po spirále.

Dalšími vhodnými př́klady je jízda stř́idavě vpřed a vzad, prŕpadně s možností postupného prodlužování cesty. Podobně lze s využitím vnořených cyklů projít několik postupně rostoucích trojúhelníků nebo čtverců. Pokud máme více robotů, lze je postavit do vrcholů n-úhelníků a nechat je procházet stejný n-úhelník společně. Dobrodružstvím se může stát jízda pěti robotů po pentagramu. Při nastavení vhodných vzdáleností se roboti ve středu potkají a plynule se minou (nesrazí se).

Podmíněné opakování (lekce 2 a 3 ) lze procvičovat na úkolech využívajících různé senzory. Robot může jet vpřed, dokud nenarazí na překážku (dotykový senzor) nebo dokud nezazní zvukový signál (zvukový senzor). Poté se může otočit do jiného směru nebo zastavit. Tyto činnosti může robot vykonávat i opakovaně, v cyklu. Zajímavým úkolem je postupné snižování rychlosti robota při setkávání se s překážkou (pokaždé se musí od překážky odrazit) až do jeho úplného zastavení. Jiným př́kladem pro využití podmíněných příkazů může být změna směru robota při tlesknutí.

Podmíněné př́ikazy a ultrazvukový senzor umožňují řešit úkoly na přesnějši prostorové vymezení pohybu robota (lekce 4). Programově lze definovat „Zvědavého“ robota, který se při detekci překážky $\mathrm{k}$ ní začne přibližovat stále pomaleji, nebo robota „ignoranta“, který se ke každé překážce $\mathrm{v}$ určité vzdálenosti otočí zády. Podnětným úkolem je tvorba parkovacího asistenta, tj. zvuková detekce blízké překážky podle vzdálenosti.

Později lze řešit složitější úkoly, např́klad změna funkce tlačítek na robotické kostce a jejich přeprogramování (lekce 5) nebo s využitím světelného senzoru (lekce 6) detekce různých barev na podložce, jízda po barevném vodícím pruhu nebo naopak hledání cesty $\mathrm{z}$ labyrintu barevně zvýrazněného na podložce.

Na závěr je dobré zařadit řešení rozsáhlejších projektů využívajících všechny předchozí znalosti. Pro tyto projekty je vhodně upravit také okolní prostor - sestavit bludiště, překážkovou dráhu nebo vhodné hřiště. V rámci projektu se studenti snaži dostat robota $\mathrm{z}$ bludiště nebo projít labyrintem. Robota lze naučit zaparkovat na označené místo nebo vyjet $\mathrm{z}$ omezeného prostoru.

V praktické výuce je výhodné, pokud je stavebnic Lego Mindstorms $\mathrm{k}$ dispozici více a studenti mohou být rozdělení do skupin, $\mathrm{v}$ rámci nichž řeší problémy s robotem samostatně. Skupiny mohou řešit různé úkoly a vzájemně se pak obohacovat při prezentaci svých výsledků nebo mohou soutěžit v hledání nejoptimálnějšího řešení jednoho konkrétního úkolu. Orientace na problémy a společné hledání řešení povzbuzuje sociální procesy vedoucí ke komunikaci a kooperaci [15]. Pokud není možnost skupinové práce, lze ve třídě pracovat $i$ s jedním robotem a problémy řešit společně $\mathrm{s}$ celou třídou.

\subsection{E-learningová podpora výuky}

Pro podporu výuky programování $\mathrm{v}$ jazyce Java byl vytvořen e-leanringový kurz $\mathrm{v}$ prostředí Moodle [10]. Kurz je členěn do devíti kapitol. V úvodu se studenti seznámí se stavebnicí Lego Mindstorms, s jednotlivými díly a způsoby skládání dílů. Pokusí se také o sestavení robota bud' podle návodu, nebo podle dle vlastní fantazie. $V$ této části kurzu nalezne zájemce také informace o potřebných instalacích a úpravách firmwaru v robotické kostce tak, aby bolo možné robota ř́́dit pomocí př́kazů jazyka Java. Úvod kurzu je věnován také stručnému popisu základů objektově orientovaného programování a deklaraci proměnných $\mathrm{v}$ jazyce Java. Tyto 
znalosti, jak bylo naznačeno výše, jsou předpokladem pro úspěšné absolvování kurzu.

Hlavní část kurzu je věnována základům programovacího jazyka Java a také ovládání robota pomocí programů v tomto jazyce. Průběh výuky a rozdělení kapitol odpovídá tabulce 1.

V závěru kurzu se studenti seznámí s dalšími možnostmi robotických stavebnic firmy Lego. Tématem kapitoly je stavebnice Lego WeDo a možnosti ovládání sestavených staveb pomocí programového prostředí Scrach [9].

Kapitoly kurzu mají jednotnou strukturu. V úvodu je motivační interaktivní prvek prezentující učivo probírané $\mathrm{v}$ dané kapitole. Následují cíle kapitoly, čas potřebný ke studiu a klíčová slova. Výklad naleznou studenti ve třech variantách:

- ve variantě elektronické on-line knihy členěné do podkapitol;

- ve formě souboru PDF určeného pro tisk;

- ve formě animovaného tutoriálu, který učivo stručně shrnuje a vhodně graficky prezentuje.

Animované video tutoriály jsou hlavním př́nosem kurzu. Kromě stručného popisu obsahují grafické prvky ilustrující základní programové konstrukty jazyka Java. Pro tyto účely byly pro jednotlivé programové struktury navrženy jejích grafické reprezentace (viz obrázek 1 - grafická reprezentace cyklu for). Hlavička cyklu (rámeček nahoře) se v průběhu animace mění a znázorn̆uje aktuální hodnotu proměnné cyklu a zbývající počet opakování. Tělo cyklu obsahuje jednotlivé př́kazy ve formě stručného popisu (přesné príkazy programovacího jazyka jsou uvedeny v textových materiálech). Průběh výpočtu je v průběhu animace znázorňován pomocí pohyblivého ukazatele vlevo.

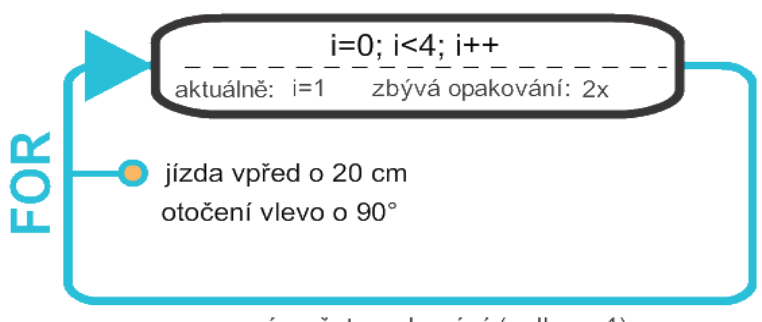

pevný počet opakování (celkem 4)

Obrázek 1: Průběhu výpočtu v cyklu for

Současně s animací průběhu výpočtu, která probíhá $\mathrm{v}$ rámci grafického znázornění dané programové struktury, je aktuální činnost robota (pohyb vpřed, otáčení, zvukový signál apod.) znázorňována na videozáznamu.

Součástí e-learningového kurzu jsou také korespondenční úkoly k jednotlivým kapitolám. Tyto úkoly lze využít zejména jako námět pro praktickou práci s robotem prímo $\mathrm{v}$ hodině.

Na závěr kurzu studenti absolvují závěrečný test. Ten sestává z 20 otázek testujících teoretické znalosti o senzorech robota a jejich využitelnosti a také o základních programových strukturách, jež jsou v rámci kurzu probírány.

Kurz je př́stupný na internetové adrese $<$ http://kik.osu.cz/moodle/> pod názvem Programování LEGO roboti̊.

\subsection{Zkušenosti z praktické realizace výuky}

Robota Lego Mindstroms využíváme

ve výuce již několik let, obvykle hlavně $\mathrm{v}$ předmětech zaměřených na didaktiku informatiky. Jedná se pouze o úvodní seznámení studentů s robotem zaměřené na předání informací o možnostech jeho uplatnění ve výuce na základních a středních školách. Používáme robota standardně sestaveného, změnou sestavy se zabýváme pouze okrajově. K ovládání robota použiváme příkazy zadávané prrímo přes robotickou kostku nebo přes jednoduché programové prostředí NXT-G. Pracujeme s jedním robotem, řešení drobných úkolů hledáme společně. Pracujeme krok po kroku podle metodiky vypracované pro žáky základních škol [6]. Již tato práce studenty vždy zaujme a podnítí $\mathrm{k}$ dalšímu přemýšlení a $\mathrm{k}$ hledání uplatnění robotických stavebnic na školách, kde působí, nebo v zájmových kroužcích.

Rostoucí zájem studentů dal podnět $\mathrm{k}$ tvorbě e-learningového kurzu pro podporu výuky programování $\mathrm{v}$ jazyce Java. Jazyk Java byl vybrán zejména $\mathrm{z}$ důvodů poměrně vysoké náročnosti předmětu zaměřeného na výuku objektově orientovaného programování $\mathrm{v}$ Javě. $\mathrm{V}$ rámci tohoto předmětu byl kurz také implementován do výuky a prakticky ověren.

Výuka základů programování v jazyce Java s orientací na objektově orientované programování je určena kombinovaným studentům, kteří v semestru absolvují pouze tři tutoriály. Robot byl využit ve výuce během závěrečného tutoriálu určeného k opakování. $\mathrm{K}$ dispozici byl pouze jeden robot, který byl předem standardně sestaven podle návodu a připraven $\mathrm{k}$ použití $\mathrm{s}$ firmwarem pro Javu. Počítač, který komunikoval s robotem přes Bluetooth, byl napojen na dataprojektor tak, aby 
všichni studenti mohli sledovat programové př́kazy a práci robota.

Využití robota Lego Mindstorms během tutoriálu si vyžádalo začít od úplného začátku, od deklarací proměnných, definic trí́d včetně definice atributů a metod až $\mathrm{k}$ vytváření objektů. V další fázi výuky byly procvičeny cykly různých typů a jejich využití v reálném prostředí. Postupné seznamování se s jednotlivými senzory robota umožnilo zopakovat a procvičit podmíněné př́kazy a definice jednoduchých i složitějších podmínek.

Implementace robota Lego Mindstorms v kombinované výuce se ukázala jako velice vhodná. Studenti ocenili, že výuka začala opakováním, které však prezentovalo pro ně již známé základní pojmy novým způsobem. Ocenili také možnost zopakovat si a procvičit základní programové struktury (opakování a větvení) na př́kladech blízkých reálným situacím, do nichž se denně dostávají, např́ílad při cestě do práce nebo do školy. V okamžiku byli schopni sami vymýšlet a formulovat další úkoly a hledat jejich řešení. Jeden ze studentů, učitel na střední škole, se $\mathrm{v}$ průběhu krátké doby pokusil o zakoupení robotických stavebnic a změny ve výuce informatiky na své škole směrem $\mathrm{k}$ výuce programování v Javě s využitím stavebnic Lego Mindstorms.

$\mathrm{V}$ závětu tutoriálu se rozvinula debata o důležitosti a rozšiřrení jazyka Java, a to zejména s ohledem na pracovní trh. Studenti formulovali dokonce potřebu rozšířené výuky jazyka Java, nejlépe hned od začátku bakalářského studia.

\section{Závěr}

Algoritmizace a programování patří mezi nejnáročnější oblasti informatiky a jejich výuka je proto velice obtížná. Velkým problémem je zejména to, že výsledky a pokrok ve studiu této oblasti se dostavují jen velice pomalu, programování vyžaduje hodně času, zkoušení, tvoření a zejména trpělivosti. To má za následek pokles zájmů a motivace ke studiu tohoto odvětví informatiky. Jeho význam je přesto velký. Algoritmizace je jednou ze základních myšlenek informatiky, která se prolíná všemi fázemi vývoje softwaru a uplatní se při jakékoliv práci $\mathrm{s}$ počítačem.

Motivací $\mathrm{k}$ výuce programování může být výběr vhodného programovacího jazyka. V tomto směru má jazyk Java výhodu; je nezávislý na platformě a využíván a rozš́iřen do mnoha oblastí. Zájem studentů lze zvýšit také vhodnou strukturou a celkovým konceptem výuky. Využití stavebnic Lego Mindstorms je jednou z těchto možností.

Jak již bylo uvedeno, mají roboti v jakémkoliv vyučování schopnost zaujmout a motivovat k práci a studiu. Výuka základů programování s využitím robotů je proto pro studenty velice vítanou formou, a to $\mathrm{z}$ několika důvodů:

- Lego Mindstorms byly navrženy speciálně pro vzdělávání.

- Roboti jsou svoji stavbou blízcí člověku, a proto $\mathrm{s}$ jejich pomocí lze řešit reálné situace blízké každodenním situacím.

- Řešení lze snadno zkontrolovat podle aktuálního chování robota.

- Č́sti robota (kostka, servomotory, senzory) jsou prŕmo ,provázané“ $\mathrm{s}$ jednotlivými algoritmickými strukturami (větvením, opakováním apod.).

- S robotem vždy pracuje skupina studentů, tj. výuka povzbuzuje sociální procesy.

Výuka programování v jazyce Java s využitím Lego Mindstorms se ukazuje jako velice vhodná, rozhodně představuje pro studenty př́ijemné zpestření klasické vysokoškolské výuky, je pro ně podnětná a motivující.

Výuka s využitím Lego Mindstorms má jistě i svá úskalí. V praktické výuce jsme se setkali zejména s těmito problémy:

- Výuka je finančně náročná. Stavebnice Lego Mindstorms jsou poměrně drahé, k ovládání robotů jsou potřeba počítače s možností komunikace přes Bluetooth.

- Vybavení škol stavebnicemi neřeší možnost domácí př́pravy studentů. Studenti se pak doma setkávají s jiným prostředím a úkoly než ve škole.

- Skupinová práce povzbuzuje sociální procesy, současně ale přináší i řadu problémů - někteří studenti pouze přihlíží nebo se o práci vůbec nezajímají, někdo se cítí hendikepován apod.

Do budoucna počítáme $\mathrm{s}$ dalším využitím Lego Mindstorms ve výuce, a to zejména s využitím e-learningového kurzu, který podrobně popisuje základní struktury jazyka Java. Prakticky zaměřená výuka se ukazuje prŕnosná pro studenty, využití Lego Mindstorms naznačeným způsobem $\mathrm{v}$ tutoriálu zaměřením na opakování se prokázalo jako vhodné.

V budoucnu bude jistě nutné přehodnotit také požadavek studentů na komplexní proměnu struktury výuky algoritmizace a programování celého studijního oboru a př́ípadnou změnu jeho 
zaměření na programování $\mathrm{v}$ jazyce Java již od počátku bakalářského studia. Pro zachování stávajícího stavu (viz úvod) mluví jednoznačně všechny výhody programovacích jazyků (Pascal, Python, Logo) navržených speciálně pro vzdělávání - jejich promyšlená struktura, promyšlený a ověřený způsob a metodika výuky, schopnost podpořit tvorbou programů $v$ těchto jazycích myšlení (algoritmické myšlení, abstraktní uvažování a představivosti apod.). Jazyk Java vzhledem $\mathrm{k}$ dưvodům svého vzniku a vzhledem $\mathrm{k}$ jeho primárnímu využití pro web mnoho z těchto výhod postrádá. Pro jeho zařazení do výuky již od počátku vysokoškolského vzdělávání mluví zejména jeho rozšiřrenost a požadavky trhu práce.

$\mathrm{Na}$ závěr nutno podotknout, že $\mathrm{v}$ roce 2014 byla uvedena nová verze robotických stavebnic označena EV3 (proti zde uváděné verzi NXT). Do budoucna plánujeme inovaci studijních materiálů a využití nové verze robotů Lego Mindstorms ve výuce programování.

\section{Literatura}

[1] ARNOLD, J. LEGO Robotics with Java. Bern: Bern university, 2014. URL:

<http://www.legorobotik.ch/legoEnglish/>

[2] BARNES, D. J. Teaching Introductory Java through LEGO MINDSTORMS Models. SIGCSE'02. Covington, 2002.

[3] FUTSCHEK, G. Logo-like Learning of Basic Concepts of Algorithms - Having Fun with Algorithms. EuroLogo 2007. Bratislava: Univerzita Komenského, 2007. s. 51.

[4] GANDY, E. A. a kol. The use of Lego Mindstorms NXT Robots in the Teaching of Introductory Java Programming to Undergraduate Students. Innovation in Teaching and Learning in Information and Computer Sciences. 9(1) 2010. eISSN: 1473-7507. URL: <http://journals.heacademy.ac.uk/doi/abs/10.111 20/ital.2010.09010002>
[5] HLINOVSKÝ, M. RoboSoutěž. Praha, ČVUT, 2013. c2010, [cit. 2014-01-21] URL: $<$ http://www.robosoutez.cz/>

[6] JAKEŠ, T. Robotické vzdělávání. Plzeň, Západočeská univerzita, 2012. URL: <https://lego.zcu.cz/web/>

[7] KRPEC, R., AMBROZKOVÁ, D., KOCICHOVÁ, D., NAGYOVÁ, I. Matematika, informatika a robotika. Ostrava: Ostravská univerzita, 2011. ISBN 978-80-7464-012-4.

[8] Lego Mindstorms. URL:

<http://www.lego.com/cs-cz/mindstorms/>

[9] LEGO Wedo and Scrach. URL: $<$ http://info.scratch.mit.edu/wedo>

[10] MAROSZ, Z. Programování LEGO roboti̊ - e-learningový kurz. Ostrava: Ostravská univerzita, $2013 . \quad$ URL:

<http://kik.osu.cz/moodle>

[11] NAGYOVÁ, I. Learning of Dynamic Data Structures - Having Fun with Algorithms. Constructionism 2010. Paris: The American University of Paris, 2010. s. 74.

[12] PAPERT, S. Perevorot v soznanii : deti, komp'jutery $i$ plodotvornyje idei. Moskva: Pedagogika, 1989. ISBN 5-7155-0004-4

[13] PELCOVÁ, K. Rozvoj algoritmického myšlení pomocí Lego Mindstorms. Spomocník. Praha: Metodický portál RVP, 2013. URL: <http://spomocnik.rvp.cz/clanek/17073/ >

[14] SCHUBERT, S., SCHWILL, A. Didaktik der Informatik. Heidelberg: Spektrum, 2004.

[15] VYGOTSKY L. S. Mind in society: the development of higher psychological processes. Cambridge: Harvard University Press, 1978.

RNDr. Ingrid Nagyová, PhD.

Katedra informačních a komunikačních

technologií

Pedagogická fakulta OU

Mlýnská 5

701 03, Ostrava, ČR

Tel: +420 597092630

E-mail: ingrid.nagyova@ osu.cz 